\title{
Precursor Plasma Cell Count
}

National Cancer Institute

\section{Source}

National Cancer Institute. Precursor Plasma Cell Count. NCI Thesaurus. Code C74619.

The determination of the number of precursor plasma cells present in a sample. 